\title{
2016 Asia Pacific Real Estate Research Symposium Special Issue
}

Published online: 24 May 2019

(C) Springer Science+Business Media, LLC, part of Springer Nature 2019

We are pleased to put together the 2016 special issue from the Asia Pacific Real Estate Research Symposium. The 2016 symposium is novel in that it was the first time the symposium is held in Seoul, South Korea.

Co-hosted by Konkuk University and KDI School of Public Policy, a total of 10 papers were presented, most of which are focused on the Asia Pacific real estate markets. This is a milestone in that high quality research focusing on Asia Pacific real estate markets was scant when the symposium was started more than 10 years ago.

Gong forward, the symposium will continue to encourage submissions of high quality real estate research centered on Asia Pacific markets.

Special Issue Editors

Seow Eng ONG

Gang- Zhi FAN

Man CHO

Publisher's Note Springer Nature remains neutral with regard to jurisdictional claims in published maps and institutional affiliations. 